\title{
Forecast of mining companies development with respect to their reclamation duties
}

\author{
J. Dvořáček VŠB, Technical University of Ostrava, Czech Republic \\ R. Sousedíková Vঙ̌B, Technical University of Ostrava, Czech Republic \\ J. Štěrba Larumo Mining - CZ, s.r.o., Czech Republic \\ R. Zapletalová Kamenolomy $\check{C} R$, s.r.o., Czech Republic
}

\begin{abstract}
This paper concerns itself with the financing of reclamation of land in the Czech Republic. By analysing a sample of 33 mining enterprises it shows that the majority of these firms do not currently have sufficient funds for financing reclamation activities. The development of reclamation funds depends on whether the enterprises are on a sound financial footing. To predict the economic development of 33 mining enterprises, the discriminate analysis method was applied. Nine firms have been selected as being in jeopardy of default. Further analyses provided the conclusion that four firms out of the nine show that jeopardy of default is imminent. They have no funds for financing reclamation activities, these costs, if need be, would have to be covered by the state. Forecasting corporate development can be an efficient tool for the state mining authorities who regulate provisioning and employment of reclamation funds.
\end{abstract}

\section{Introduction}

Mining activities have a major impact on the environment, and may be the reason, or just pretext, for public protest. Reclamation activities, which improve or restore damage caused by mining, are a way of reducing such protest. Actual reclamation activities have two aspects; technical and economic. The creation of reclamation funds in the European Union Countries is based either on mining or environmental legislation (Dvořáček et al., 2005) which means that there are countries in which:

- Creation of the reclamation funds is compulsory, e.g. in the Czech Republic, Germany, Poland, Latvia and Slovenia.

- State mining authorities have earmarked funding at their disposal to pay for reclamation costs if a mining enterprise fails to comply with its duty, e.g. Greece, Spain, France and Lithuania.

As part of the first group, the mining industry in the Czech Republic is obliged to create funding for reclamation, as the situation is an outcome of a longer process of development.

\section{Developments of reclamation financing}

The subject of the reclamation fund provision in the Czech Republic was detailed last year (Dvořáček et al., 2008b). The years of 1991 and 2004 are of major importance. Mining legislation amendments of 1991 required the creation of funds that would be used for reclamation of land affected by mining activities. Nevertheless this law does not state the method of creating these funds. Only since 2004, has it been obligatory to create cash reserves for mining damage compensation and land reclamation. There is a special account within the company's bank for this purpose and the money is tax deductible.

Currently the problem of paying reclamation costs in the Czech Republic is that the majority of the funds reserved for this purpose are fictitious, as they are of accounting character only. Mining company balance sheets are evidence of this. The sheet's financial sources side contains equity and liabilities including total reserves, and the tax allowable reserves (lawful reserves) are part of these total reserves. Here, mining companies can book reserves for maintenance of fixed assets, reserves for reclamation of land affected by mining, and mining compensation reserves. Other specific lawful reserves concern banks, insurance 
companies and agricultural enterprises. Lawful reserve provisions reduce the base for calculations of income taxes, which provides for postponed booking of a part of net income, and consequently postpones payments of taxes. On the contrary, if reserves are employed, income taxes increase.

Other non-taxable (accounting) reserves can be also created - concerning, for example, costs of restructuring, for emergency provisions or losses. The creation and employment of these reserves is at the discretion of a mining company, and they do not influence the income tax base. The sheet's property side includes also current assets - of which financial assets are included. This concerns primarily cash and money deposits.

If money deposits constituted lawful reserves, financial assets would exceed lawful reserves. Verifying this hypothesis, levels of financial assets were compared with those of reclamation reserves for 33 mining companies in the Czech Republic. The list includes the largest surface and underground mining enterprises, as well as small quarries. It was found that one third of these firms had their financial assets smaller than balance sheet reclamation reserves and that:

- Apart from lawful reclamation reserves, mining companies create reserves for maintenance of fixed assets.

- Apart from lawful reserves, mining companies can also create other (accounting) reserves.

- Financial assets must ensure paying of other debts and provide for financing of other mining related activities.

As such it is obvious that reclamation reserves are not sufficient to pay for realisation of land reclamation activities.

The State Mining Authority is responsible for the supervision of creating and employing the reclamation reserves, which means that the provision of reserves is subject to approval of the district mining authority. The District Mining Authority approves employment of the reclamation reserves after consultation with the Ministry of the Environment.

It is possible to assume that sufficient levels of reserves will be reached when planned termination of activities of particular companies (mine closure) is due. Nevertheless, for the time being, continued existence of these companies is necessary, and it might be useful for the State Mining Authority to have a tool of predicting economic development of mining companies, which the State Mining Authority is responsible for.

\section{$3 \quad$ Predicting economic development of mining companies}

Economic problems of mining companies are often a fundamental cause of their failure to perform duties of land reclamation. If a company cannot pay its debts properly, default is imminent. If the State Mining Authority was able to predict the economic development of companies at least two years ahead, it could, in case of unfavourable prognosis, take appropriate action. This could make impacts on the state, and consequently tax payers, less severe.

Economic development of companies is associated with circulation of capital. At the beginning there is capital provided by internal or external sources. This capital participates in the production process in forms of fixed assets, current assets, and hired workforce. The results of production processes are products and services. Having been sold, products and services transform into receivables that, if they are paid, change into capital again. The capital provides for starting of a new production circle. It pays for consumed current assets, wages and salaries, and in due time for fixed assets renewal as well. Other financial sources can be used for starting of a new production circle - alternative deposits of owners, loans, etc. — so that expanded reproduction of assets is possible.

The renewal of assets and payments of wages and salaries must be performed continuously. Otherwise incomplete reproduction follows, which means reduction of company's wealth and reduced numbers of staff, i.e. a process that reaches its limits fast. Capital circulation disturbances mean that less capital is disposable for the reproduction, which implicates necessity of further deposits or loans. Nevertheless, this is possible only for a limited period of time. 
Within this theoretical framework, it is possible to suggest criteria for assessment of the future economic performance of corporate businesses. The criteria should take into account the company's capital circulation; corporate wealth structures; rates and trends of indebtedness; liquidity; and production trends of development. The criteria are chosen, assuming that their values will be different, in regards to immaculate performance of non-bankrupt firms' vis-à-vis those in default. In the 1930s, simple comparison of values of financial ratios was used for predicting future economic performances of corporate businesses (Koundinya et al., 2004). A more sophisticated method of working with ratios characterising non-bankrupt and bankrupt firms is the method of discriminate analysis. This method starts with a file of firms that have been structured into two classes, namely those of non-bankrupt and bankrupt businesses. Each firm of the file is characterised by ratio values that are called discriminators. Working with the file, the objective is to determine a discriminate function that would provide for identifying of any other firm that has been characterised by a similar set of discriminators, as successfully operating or threatened by default.

\subsection{Applying discriminate analysis}

The discriminate analysis enables evaluation of differences between two or several groups of objects characterised by several attributes. The classical discriminate analysis belongs to methods of investigation that look at a group of independent attributes (discriminators) and a single qualitative dependant variable; output. The simplest case is represented by a binary variable output of 0 value if objects belong to Class I, and of value 1 if objects belong to Class II. The classes are known to be clearly distinctive in that each object belongs indisputably to one of them. The objective is to identify a prediction model providing for classification of new objects, i.e. incorporating them into Class I or II. This model starts with discriminate function coefficient values and a value of an optimum threshold point, C. Concerning the assessed firms, the discriminate function coefficient values and the values of respective discriminators provide for calculating discriminate function values that are compared to values of C. An unclassified firm whose linear discriminate function value exceeds point $\mathrm{C}$ can be incorporated to a class of non-bankrupt firms. If the linear discriminate function value is lower than $\mathrm{C}$ the firm is classified as threatened by bankruptcy (Dvořáček et al., 2008a).

The reason for choosing the discriminate function method for our investigation was that traditional methods of corporate economic development evaluate ratio indices one-dimensionally. The interpretation of the values of such indices may be ambiguous. The discriminate analysis enables incorporation of a greater number of ratio indices into a single model, and as such provides for a more complex, multi-dimensional evaluation of the investigated firm.

Our application of the discriminate analysis started with a group of non-bankrupt businesses and firms declared bankrupt. Each group comprised 85 companies that were characterised by the same levels of total assets in the last balance sheet. The bankruptcy declarations were issued in the period 1997-2008 and the majority of bankruptcies (40) were declared in the years 2003-2005. The number of bankruptcies in individual years was influenced only by availability of respective accounting documents. Data on nonbankrupt firms were acquired between 2003 and 2008. The firms were qualified as non-bankrupt if their last and preceding year balance sheets and profit and loss accounts documented profitability. Approximately half of the non-bankrupt firms are mineral extraction businesses or businesses that are at least partly involved in mineral extraction activities. The State Mining Authority's database of the mining firms was made available to us. The group of bankrupt firms comprised of various companies in the Czech Republic; industrial enterprises, building companies, agriculture, services and commerce.

The period between bankruptcy declarations and the last issues of the balance sheets and profit and loss accounts was six months on average. In a few individual cases the basic accounting documents were issued one day before bankruptcy was declared. With regards to non-bankrupt businesses, the average period between investigation and the issue of accounting documents was 17 months. This was because of their availability on the internet, where occasionally, related accounting documents were published with considerable delay. 
The key factor for application of discriminate analysis was the choice of indicators for specific discriminate function coefficients - discriminators. Taking into account the theory outlined in the introduction, namely that disturbances of capital circulation are causes of bankruptcy, the following discriminators related to capital circulation were chosen:

$$
\text { Measure and indebtedness: } \quad \text { I. } \quad \frac{\text { Total Liabilities }}{\text { Total Assets }}
$$

A company's property is also financed by external resources and hence the measure of indebtedness.

Development of indebtedness: $\quad$ II. $\quad$ index: $\frac{\text { Total Liabilities }}{\text { Total Assets }}$

A measure of indebtedness as pertinent to a particular date, usually end of the year, and related to the measure of indebtedness of the preceding year, hence concerns the development of indebtedness.

$\begin{array}{lll}\text { Production development: } & \text { III. } & \begin{array}{l}\text { Current Assets } \\ \text { IV. }\end{array} \\ & \text { V. } & \frac{\text { Paduction Index }}{\text { Total Assets }} \\ \text { Relationship to firm's liquidity: } & \text { VI. } & \frac{\text { Financial Assets }}{\text { Current Assets }} \\ & \text { VII. } & \frac{\text { Current Liabilities }}{\text { Total Assets }} \\ \text { Wealth structure: } & \text { VIII. } & \frac{\text { Current Assets }}{\text { Total Assets }}\end{array}$

Note that the discriminators VI and VII do not relate to commonly accepted indicators of liquidity. The discriminator VI means that increased shares of financial assets in current assets increase the company's solvency, i.e. also liquidity. In such situations, shares of current liabilities in assets go down. A contrary scenario is possible and is also related to liquidity. Concerning the discriminator IV it can be noted that the item of production includes sales of goods and services, and change of stock and consumption of selfproduced goods. Apart from the importance of choosing the appropriate quality discriminators, it is also important how many of them are taken for discriminate analysis applications. Here we believe the measure of accuracy is the feedback information on the prediction success, i.e. to what extent the companies have been correctly assessed as threatened by default or whether rather positive economic development can be expected.

\subsection{Results and discussion}

Concerning collections of 85 non-bankrupt and 85 bankrupt companies, the discriminate analysis was applied four times in total. At the beginning, five designated discriminators, I-IV, VI were applied and then discriminators V, VII and VIII were being added to the applications. This means that the number of discriminators used grew from five up to eight as designated, I-VIII. Coefficients of linear discriminate function and values of optimum threshold points were calculated. The latter was used for classifying individual companies. Using discriminator values, classified files of non-bankrupt and bankrupt companies were tested for prediction accuracy. Shares of correctly classified companies in each category, as related to the total number of 170 companies, expressed percentage rates of prediction accuracy. This accuracy interval for non-bankrupt firms was $78.8-84.7 \%$, and $90.6-91.8 \%$ regarding bankrupt companies.

This feedback classification has demonstrated that the results of discriminate analysis are useful for predicting corporate development in a period of one to two years. As such the results of discriminate analysis were applied to a sample of 33 mining companies in the Czech Republic, primarily quarries. Approximately 
half of the company's financial reserves for reclamation of land were compared with their financial assets. Economic development predictions were performed for companies whose principal of activity was mining.

On grounds of discriminate analysis, using five to seven discriminators, eight companies were qualified as threatened by default. If eight discriminators were used for analysis, seven firms would show as default threatened. In total, nine different firms were qualified as bankruptcy candidates, where seven of them were qualified by using five to eight discriminators. It was necessary to find the reasons for this threat of bankruptcy.

From the point of view of mathematics, qualifying a firm bankrupt or non-bankrupt depends on the value of the linear discriminate function. If coefficients of the linear discriminate function are constant, the discriminate function value is determined by individual discriminators of particular firms. Comparing discriminator values of firms threatened by default with average values of discriminators of the whole file of the related company category can reveal causes of qualifying firms as bankruptcy threatened. Analysing balance sheets and profit and loss accounts of nine firms of possible default resulted in dividing them into groups of wrongly qualified and of imminent default respectively.

The group of wrongly classified firms - the initial discriminate analyses prognostication was that these firms were threatened by default but further investigations could prove that their situation was not hopeless. Five firms can be put into this group, where five of them had the discriminator value - financial assets/current assets - amounting to $1 / 3-1 / 10$ of the average value of non-bankrupt indicators. This low value was caused by:

- Financial management of the company's owner from abroad (depletion of company's free financial assets): two firms.

- Sale difficulties and bad financial situation: three firms.

These firms indicated decreased values of total liabilities. Net income and accumulated earnings were mostly positive. Nevertheless, production went down in all cases, which was the principal cause of economic difficulties. Analytical results showed that these firms were not threatened by bankruptcy. From the mathematical point of view, the result was influenced by high coefficient of linear discriminate function, concerning the discriminator financial assets/current assets.

The group of firms for which the bankruptcy threat was imminent - firms were prognosticated as poorly operating and further analysis proved the point up to the conclusion that these firms would not be able to meet their obligations of reclamation. Four firms could be included in this group. All of them indicated excessive indebtedness, i.e. they all plunged into the red and the ratio value, Financial Assets/Current Assets, was very low. Two of the four firms had this ratio lower than would be the average value of businesses in default. Another characteristic feature of the firms analysed were fully depreciated fixed assets, zero production, leased property, sale difficulties and increasing receivables. The analytic results corroborated the prediction, namely that the bankruptcy in the following one to two years was to be expected. Low values of financial assets indicate that reclamation of land will not be possible.

Concerning the sample set of 33 mining enterprises, discriminate analysis applications showed that the method signals difficulties of future economic development of these enterprises, although the results should not be applied mechanically. The analysis of causes of classifying a firm as bankrupt or non-bankrupt is an integral part of the prediction process. This especially concerns firms jeopardised by default. These firms are in the minority but the matter of accurate assessment is of greater consequence.

Also general applicability of the suggested discriminators can be questioned. It is possible to assume that economic development of corporate businesses in individual countries is similar, as are causes of default. Also the structure of basic accounting documents is analogical. Differences may concern titles and contents of specific indicators. For applications of the method abroad, it would be necessary to define in great detail the contents of indices used for construction of individual discriminators. 


\section{Conclusion}

These are possible outcomes from our analyses:

- Financial reserves to meeting reclamation duties are often insufficient and are instead for accounting purposes only.

- Reclamation reserve provisions are parallel to companies' mining activities and depend on the success of these activities.

- It might be useful for the State Mining Authority if they had an efficient tool of predicting success or failure concerning mining companies' operations.

- If a company is suspected of bankruptcy, the District Mining Authority can ask for immediate commencement of reclamation activities, they can apply stricter supervising criteria concerning creation and employment of reclamation reserves.

- The Regional Mining Authority is obliged to register mining companies' duties of reclamation, as prospective new owners of the bankrupt companies must accept all such duties.

Predicting a company's economic development is difficult, many times the causes of default are other than those implicit in economic theory. Very often is the case in the Czech Republic that companies survive on grounds where economic theory implications should not exist. Creditors support such companies and believe that the companies' economic situation will improve and that they will finally be able to pay their debts. These creditors believe that this might be more profitable than just relying on proceeds from selling assets of bankrupt firms. On the other hand, declarations of bankruptcy are often issued for reasons of fast and assured financial gains, although gains are relatively small in comparison to the company's assets. Another complicating factor of economic development predictions is in the existence of current financial and economic problems worldwide. Nevertheless, the importance of such prognostications is growing steadily, especially with regard to consequences of unexpected bankruptcies.

The discriminate analysis function is employed for assessments of corporate businesses worldwide. There is no common consent with regard to the number and kind of discriminators, homogeneity or heterogeneity of input data files, etc. As such our results cannot be taken as conclusive. If the results of discriminate analysis are completed by analysis of causes of company's classifications, the method can be regarded as promising, efficient and widely applicable.

\section{References}

Dvořáček, J., Slivka, V., Vlach, O. and Vaněk, M. (2005) Problematika financováni zahlazování následků hornické činnosti v zemích EU s rozvinutým hornictvím (Financing Recuperative Action as Regards Mining Damages in the EU Countries with Developed Mining Industries), VŠB - Technická univerzita Ostrava (VSB-Technical University of Ostrava), $90 \mathrm{p}$.

Dvořáček, J., Sousedíková, R. and Domaracká, L. (2008a) Industrial enterprises bankruptcy forecasting, Metalurgija/Metallurgy, Zagreb, Vol. 47(1), pp. 33-36.

Dvořáček, J., Štěrba, J. and Novotný, K. (2008b) The Financing of Mine Land Rehabilitation in the Czech Republic, In Proceedings of the Third International Seminar on Mine Closure, Mine Closure 2008, A.B. Fourie, M. Tibbett, I.M. Weiersbye, P. Dye (eds), 14-17 October 2008, Johannesburg, South Africa, Australian Centre for Geomechanics, Perth, pp. 161-167.

Koundinya, R., Prasad, D. and Puri, Y.R. (2004) Corporate Failure: A Judgmental Approach to Prediction, University of Massachusetts Lowell, Working Paper, In: Predicting Corporate Failure: A Comparison of Alternate Models. 